\title{
Pengaruh Penggunaan Model Pembelajaran Inkuiri Terbimbing terhadap Prestasi Belajar Fisika Siswa SMP
}

\author{
1Jono Iskandar, ${ }^{2}$ Syifaul Gummah, ${ }^{2}$ Saiful Prayogi, ${ }^{3}$ Muhammad Asy'ari \\ ${ }^{1}$ Akademi Komunitas Olat Maras (AKOM), Sumbawa Regency, Nusa Tenggara Barat, \\ Indonesia 84316 \\ 2Program Studi Pendidikan Fisika, FSTT, Universitas Pendidikan Mandalika, JI. Pemuda No. \\ 59A Mataram, Indonesia 83125 \\ ${ }^{3}$ Program Studi Pendidikan Olahraga dan Kesehatan, FIKKM, Universitas Pendidikan \\ Mandalika, Jl. Pemuda No. 59A Mataram, Indonesia 83125 \\ *Email Korespondensi: muhammadasyari@undikma.ac.id
}

\begin{abstract}
Abstrak
Pembelajaran di dalam kelas yang cenderung berpusat pada guru disinyalir menjadi penyebab rendahnya prestasi belajar siswa. Penggunaan mode pembelajaran yang tepat diharapkan mampu membuat siswa berperan aktif dalam proses pembelajaran. Penelitian ini bertujuan untuk mengetahui pengaruh model pembelajaran inkuiri terbimbing terhadap prestasi belajar fisika siswa. Jenis penelitian ini adalah quasi eksperimen dengan pretestposttest control group design. Siswa pada kelas VIII (34 siswa) dijadikan sebagai kelompok eksperimen dan siswa pada kelas $\mathrm{VIII}^{6}$ (34 siswa) sebagai kelompok control yang dipilih menggunakan claster random sampling technique. Data penelitian dikumpulkan menggunakan instrumen tes objektif yang telah diuji validitas, reliabilitas, daya pembeda dan indeks kesukaran. Perbedaan prestasi belajar siswa dianalisis menggunakan uji-t setelah dinyatakan memenuhi uji prasyarat normalitas dan homogenitas data. Berdasarkan hasil analisis data, diperoleh skor rata-rata pretest kelompok eksperimen sebesar 36,17 dan kelompok kontrol sebesar 39,5. Sedangkan skor rata-rata posttest kelompok eksperimen sebesar 65,41 dan kelas kontrol sebesar 50 . Hasil uji-t menunjukkan thitung $=6,07>t_{\text {tabel }}=2,00$, sehingga dapat disimpulkan bahwa penggunaan metode pembelajaran Inkuiri Terbimbing berpengaruh secara signifikan terhadap prestasi belajar fisika siswa SMP.
\end{abstract}

Kata kunci: model pembelajaran; inkuiri terbimbing; prestasi belajar

\section{The Effect of the Use of Guided Inquiry Learning Model on the Physics Learning Achievement of Junior High School Students}

\begin{abstract}
Learning in the classroom that tends to be teacher-centered is allegedly the cause of the low student achievement. The use of appropriate learning modes is expected to be able to make students play an active role in the learning process. This study aims to determine the effect of the guided inquiry learning model on students' physics learning achievement. This type of research is a quasi-experimental with a pretest-posttest control group design. Students in class VIII4 (34 students) were used as the experimental group and students in class VIII6 (34 students) as the control group were selected using the cluster random sampling technique. The research data were collected using an objective test instrument that had been tested for validity, reliability, discriminatory power and difficulty index. Differences in student achievement were analyzed using t-test after being declared to meet the prerequisite tests for normality and data homogeneity. Based on the results of data analysis, the average pretest score of the experimental group was 36.17 and the control group was 39.5. While the posttest average score of the experimental group is 65.41 and the control class is 50. The t-test results show tcount $=6.07>$ table $=2.00$, so it can be concluded that the use of guided inquiry learning model has a significant effect on junior high school students' physics learning achievement.
\end{abstract}

Keywords: learning model; guided inquiry; learning achievement

How to Cite: Iskandar, J., Gummah, S., Prayogi, S., \& Asy'ari, M. (2021). Pengaruh Penggunaan Model Pembelajaran Inkuiri Terbimbing terhadap Prestasi Belajar Fisika Siswa SMP. Empiricism Journal, 2(1), 10-18. https://doi.org/10.36312/ej.v2i1.515 


\section{PENDAHULUAN}

Fisika sebagai salah satu dari bagian ilmu pengetahuan yang lain, merupakan ilmu yang lahir dan berkembang lewat langkah langkah observasi, perumusan masalah, penyusunan hipotesis, pengujian hipotesis melalui eksperimen, penarikan kesimpulan serta penemuan teori dan konsep, sehingga dapat dikatakan bahwa hakikat fisika adalah ilmu pengetahuan yang mempelajari gejala gejala melalui serangkaian proses yang di kenal dengan proses ilmiah yang di bangun atas dasar sikap ilmiah dan hasilnya terwujud sebagai produk ilmiah yang tersusun atas tiga komponen terpenting berupa konsep, prinsip, dan teori yang berlaku secara universal (Trianto, 2012). Oleh karena itu, proses pembelajaran fisika di dalam kelas seharusnya menekankan pada partisipasi aktif siswa (Sukarma \& Sani, 2020) untuk mengoptimalkan transfer informasi untuk menumbuhkembangkan kemampuan berpikir yang bermuara pada peningkatan prestasi belajar siswa (Sukaisih et al., 2020). Sayangnya, pembelajaran fisika di sekolah secara empiris hanya terbatas pada hafalan dan ingatan yang diberikan oleh guru (Prayogi et al., 2013).

Hasil pra-penelitian menunjukkan bahwa metode yang digunakan guru adalah metode ceramah yang memiliki karakteristik cenderung berpusat pada guru (Gulo, 2008). Alasan guru menggunakan metode ceramah adalah kurangnya alat-alat laboratorium (Sukaisih \& Muhali, 2014) jika harus menggunakan metode lain. Dampaknya, perolehan skor siswa yang umumnya dijadikan patokan prestasi belajar siswa berada di bawah ketuntasan minimal yaitu 63,0 . Tujuan pengajaran ditetapkan dalam perencanaan pengajaran atau lebih sering dikenal dengan istilah kurikulum. Kurikulum memuat tentang isi dan pengalaman belajar yang bermuara pada pemilihan strategi, model, metode, dan pendekatan dalam pembelajaran (Hosnan, 2014). Keberhasilan implementasi kurikulum tergantung pada keterampilan guru sebagai ujung tombak pelaksanaan kurikulum di sekolah dalam memilih model pembelajaran yang relevan sesuai tuntutan pembelajaran (Sumantri, 2019).

Siswa ditekankan pada empat komponen penting yaitu pemahaman, hafalan, latihan dan keterampilan untuk meningkatkan prestasi belajar fisika siswa. Sementara, seperti yang telah diuraikan sebelumnya, kegiatan belajar mengajar IPA fisika di sekolah-sekolah masih didominasi oleh aktivitas guru, sehingga kualitas pendidikan fisika masih belum meningkat. Pembelajaran semacam ini diakibatkan oleh keterbatasan waktu belajar yang tersedia sedangkan materi yang diajarkan sangat banyak. Dengan demikian guru belum bisa mengaktifkan siswa jika pemilihan metode pembelajarannya kurang tepat (Suwandi et al., 2013). Prestasi belajar adalah hasil yang diperoleh dari aktivitas siswa yang disusun dari daerah kognitif yaitu meliputi pengetahuan, pemahaman, aplikasi, analisis, evaluasi, dan kreasi; ranah afektif meliputi penerimaan, jawaban, penilaian, organisasi dan internalisas; sedangkan ranah psikomotor meliputi gerakan reflex, keterampilan gerakan dasar, kemampuan persepektual, keharmonisan atau ketepatan, gerakan keterampilan kompeks, gerakan ekspresif dan interpreatif (Anderson \& Krathwohl, 2001). Ketiga ranah atau aspek tersebut menjadi objek dalam penilaian prestasi belajar atau hasil belajar.

Salah satu cara yang dapat dilakukan untuk meningkatkan aktivitas dan prestasi belajar siswa khususnya mata pelajaran fisika pada SMPN 1 Narmada adalah dengan menggunakan model pembelajaran Inkuiri yang lebih menekankan pada siswa untuk menemukan sendiri jawaban dari suatu permasalahan. Sehingga siswa berperan aktif didalam meningkatkan pemahaman tentang suatu konsep yang sudah dipelajari dengan guru. Penggunaan model pembelajaran yang menekankan pada aktifitas siswa seperti model pembelajaran inkuiri terbimbing (Nisa et al., 2018) perlu dilakukan. Pembelajaran Inkuiri adalah rangkaian kegiatan pembelajaran yang menekankan pada proses berpikir secara kritis dan analitis untuk mencari dan menemukan sendiri jawaban dari suatu masalah yang dipertanyakan (Asy'ari et al., 2019). Materi yang disajikan oleh guru tidak langsung diberikan kepada siswa, tetapi siswa yang mencari sendiri atau menemukan sendiri konsep-konsep yang telah direncanakan oleh guru (Arends, 2012) melalui langkah-langkah orientasi, merumuskan masalah, merumuskan hipotesis, mengupulkan data, menguji hipotesis, dan merumuskan kesimpulan (Wenning, 2011).

Berdasarkan uraian permasalahan dan latar belakang yang telah diuraikan tersebut, penelitian ini bertujuan untuk mengetahui pengaruh penggunaan metode pembelajaran Inkuiri Terbimbing terhadap prestasi belajar fisika siswa kelas VIII pada SMPN 1 Narmada. 


\section{METODE}

Penelitian ini merupakan penelitian quasi eksperimen. Penelitian ini dilaksanakan di SMPN 1 Narmada kelas VIII dengan sampel sebanyak 68 siswa (VIII 4 sebanyak 34 siswa sebagai kelompok eksperimen dan kelas VIII 6 sebanyak 34 siswa sebagai kelompok control). Adapun teknik yang digunakan dalam pengambilan sampel penelitian ini adalah claster random sampling yaitu pengambilan sampel dilakukan secara acak tanpa memperhatikan strata yang ada dalam populasi dari jumlah populasi yang ada pada siswa kelas VIII SMPN 1 Narmada yang terdiri dari 8 kelas.

\section{Rancangan Penelitian}

Penelitian ini menggunakan pretest-posttest control group design (Fraenkel et al., 2012) seperti disajikan pada Tabel 1. Penelitian diawali dengan pemberian pretest untuk mengidentifikasi pengetahuan awal siswa. Materi yang diberikan dalam pembelajaran adalah pembiasan cahaya, baik untuk kelompok eksperimen maupun kelompok kontrol. Akan tetapi diberikan perlakuan yang berbeda. Kelompok eksperimen diberikan pembelajaran menggunakan model pembelajaran inkuiri terbimbing sedangkan kelompok kontrol diberikan pembelajaran tanpa inkuiri. Pada akhir pembelajaran, kedua kelompok sampel diberikan posttest untuk mengetahui pengaruh pemberian perlakuan.

Tabel 1. Rancangan Penelitian

\begin{tabular}{ccccc}
\hline No & Kelas & Pre-test & Perlakuan & Post-test \\
\hline 1 & Eksperimen & $O_{1}$ & $X_{1}$ & $O$ \\
2 & Kontrol & $O_{1}$ & $X_{2}$ & $O_{2}$ \\
\hline
\end{tabular}

Keterangan:

$O_{1}=$ pemberian pre-test pada kelas eksperimen dan kelas control

$\mathrm{O}_{2}=$ pemberian post-test pada kelas eksperimen dan kelas control

$X_{1}=$ pemberian metode inkuiri

$X_{2}=$ pemberian tanpa metode inkuiri terbimbing

\section{Instrumen Penelitian}

Instrumen yang digunakan dalam penelitian ini adalah instrument tes objektif sebanyak 50 butir. Sebelum tes diberikan, instrument tes diujicoba di kelas VIII 2 SMPN 1 Narmada yang selanjutnya dianalisis untuk mengetahui validitas, reliabilitas, daya beda, dan taraf kesukaran. Berikut diuraikan tahapan pengujian instrument test dalam penelitian ini.

\section{Validitas Butir Soal}

Validitas adalah suatu ukuran yang menunjukkan tingkat-tingkat kevalidan atau kesahihan suatu instrumen. Dalam penelitian digunakan rumus product moment dengan angka kasar (Arikunto, 2010) sebagai berikut:

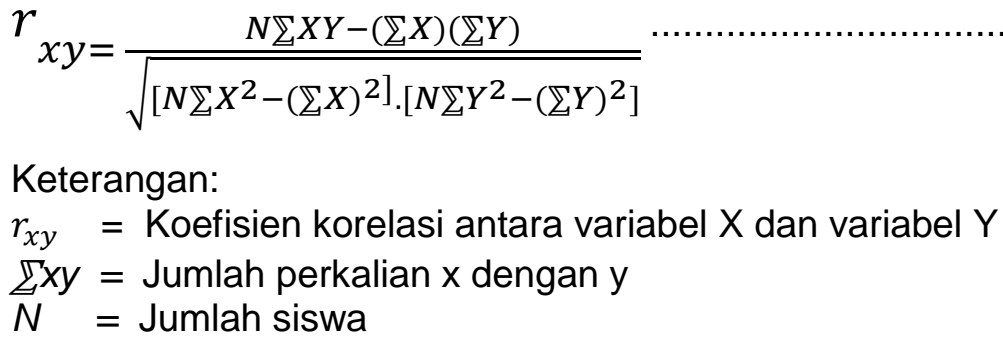

Instrument test dinyatakan valid apabila $r_{x y}>r_{\text {tabel }}$.

\section{Reliabilitas Soal}

Reliabilitas suatu tes dapat dikatakan mempunyai taraf kepercayaan yang tinggi jika tes tersebut dapat memberikan hasil yang tepat (Arikunto, 2013). 


$$
r_{11}=\left(\frac{n}{n-1}\right)\left(\frac{S^{2}-\sum p q}{S^{2}}\right)
$$

Keterangan:

$r_{11}=$ reliabilitas tes secara keseluruhan

$p=$ proporsi subjek yang menjawab item dengan benar

$q=$ proporsi subjek yang menjawab etem dengan salah $(q=1-p)$

$\sum p q=$ jumlah hasil perkalian antara $p$ dan $q$

$n$ = banyaknya item

$S=$ standar deviasi dari tes (standar deviasi akar varians)

Instrument tes dinyatakan reliable apabila $r_{11}>r_{\text {tabel. }}$. Berikut disajikan kriteria reliabilitas instrument tes pada Tabel 2.

Tabel 2. Kriteria Nilai Reliabilitas (Arikunto, 2013)

\begin{tabular}{ccc}
\hline No & Nilai & Kategori \\
\hline 1 & $0,81-1,00$ & Sangat Tinggi \\
2 & $0,61-0,80$ & Tinggi \\
3 & $0,41-0,60$ & Cukup Tinggi \\
4 & $0,21-0,40$ & Rendah \\
5 & $0,00-0,20$ & Sangat Rendah \\
\hline
\end{tabular}

\section{Daya Pembeda Soal}

Daya pembeda sebuah butir soal adalah kemampuan suatu soal untuk membedakan antara siswa yang berkemampuan tinggi dengan siswa yang berkemampuan rendah (Arikunto, 2013). Berikut persamaan dan kriteria (Tabel 3) yang digunakan untuk menentukan daya pembeda butir soal.

$D=\frac{B_{A}}{J_{A}}-\frac{B_{B}}{J_{B}}$

Keterangan:

$D=$ daya pembeda soal

$B_{A}=$ banyaknya peserta kelompok atas yang menjawab soal dengan benar.

$B_{B}=$ banyaknya peserta kelompok bawah yang menjawab soal dengan benar

$J_{A}=$ banyaknya peserta kelompok atas

$J_{B}=$ banyaknya peserta kelompok bawah

Tabel 3. Kriteria daya pembeda soal (Arikunto, 2013).

\begin{tabular}{cc}
\hline Interval D & Kriteria \\
\hline $0.00-0.20$ & Jelek \\
$0.20-0.40$ & Cukup \\
$0.40-0.70$ & Baik \\
$0.70-1.00$ & Baik sekali \\
- (negatif) & Semua tidak baik (dibuang) \\
\hline
\end{tabular}

\section{Taraf Kesukaran Butir Soal}

Soal yang baik adalah soal yang tidak terlalu mudah atau tidak terlalu sukar (Arikunto, 2013). Berikut disajikan persamaan dan kriteria (Tabel 4) untuk mengetahui tingkat kesukaran dalam penelitian ini.

$P=\frac{B}{J S}$ 
Keterangan:

$P=$ indeks kesukaran

$B$ = banyaknya siswa yang menjawab soal dengan benar

$J S=$ jumlah seluruh siswa peserta tes

Tabel 4. Kriteria indeks kesukaran soal (Arikunto, 2013)

\begin{tabular}{cc}
\hline Interval P & Kriteria \\
\hline $0.00-0.30$ & Sukar \\
$0.30-0.70$ & Sedang \\
$0.70-1.00$ & Mudah \\
\hline
\end{tabular}

\section{Teknik Analisis Data}

\section{Uji Homogenitas}

Uji homogenitas dilakukan untuk membuktikan apakah kedua sampel yang menjadi objek penelitian homogeny atau tidak (Subana \& Sudrajat, 2009). Berikut persamaan matematis yang digunakan untuk menentukan homogenitas data penelitian ini.

$$
F=\frac{(\text { Varians Terbesar })}{\text { (Varians Terkecil) }}
$$

Dengan kriteria pengujian yaitu jika : $F_{\text {hitung }} \geq F_{\text {tabel }}$ maka data tidak bervarian homogen, sedangkan jika $: F_{\text {hitung }} \leq \mathrm{F}_{\text {tabel }}$, maka data bervarian homogen pada taraf signifikan $(\alpha)=$ $5 \%$

\section{Uji Normalitas}

Uji normalitas digunakan untuk mengetahui distribusi data yang diperoleh dari gejala yang diselidiki (Riduwan, 2008). Berikut persamaan matematis yang digunakan untuk mengetahui normalitas/distribusi data hasil penelitian ini.

$$
\chi^{2}=\sum_{i=1}^{k} \frac{\left(f_{o}-f_{e}\right)^{2}}{f_{e}}
$$

Di mana:

$x^{2} \quad=$ Chi kuadrat

$\mathrm{f}_{\mathrm{o}} \quad=$ Frekuensi hasil pengamatan

$\mathrm{f}_{\mathrm{e}} \quad=$ Frekuensi hasil harapan

Data penelitian dinyatakan berdistribusi normal jika $x^{2}$ hitung $<x^{2}$ tabel

\section{Uji Hipotesis}

Hipotesis penelitian ini diuji menggunakan persamaan uji t setelah data hasil penelitian dinyatakan berdistribusi normal dan bervarian homogen. Persamaan matematis yang digunakan untuk menguji hipotesis dalam penelitian ini diuraikan sebagai berikut (Arikunto, 2013).

$$
t=\frac{M_{x}-M_{y}}{\sqrt{\left(\frac{\sum x^{2}+\sum y^{2}}{N_{x}+N_{y}-2}\right)\left(\frac{1}{N_{x}}+\frac{1}{N_{y}}\right)}}
$$

Di mana:

$\mathrm{T}=$ Harga t untuk sampel terpisah dan varian hiterogen

$\mathrm{M}=$ Nilai rata-rata hasil per kelompok

$\mathrm{N} \quad$ = Banyaknya subjek

$\mathrm{x} \quad=$ Deviasi setiap nilai $x_{2}$ dan $x_{1}$

$\mathrm{y}=$ Deviasi setiap nilai $y_{2}$ dari mean $y_{1}$ 
dan $\sum x_{2}=\sum X^{2}-\frac{\left(\sum X\right)^{2}}{N}$ dan $\sum y^{2}=\sum Y^{2}-\frac{\left(\sum Y\right)^{2}}{N}$

Adapun kriteria hipotesis penelitian ini adalah (1) jika $t_{\text {-hitung }}>t_{\text {-tabel, }}$ Ha diterima dan Ho ditolak (ada pengaruh penggunaan model pembelajaran inkuiri terbimbing terhadap prestasi belajar fisika pada siswa kelas VIII SMPN 1 Narmada), (2) jika $t_{\text {-hitung }}<\mathrm{t}_{\text {-tabel, }}$, Ha ditolak dan Ho diterima (tidak ada pengaruh penggunaan model pembelajaran inkuiri terbimbing terhadap prestasi belajar fisika pada siswa kelas VIII SMPN 1 Narmada), dan (3) jika $t_{\text {-hitung }}=t_{\text {-tabel }}$ berarti Ho diterima dan Ha ditolak (tidak ada pengaruh penggunaan model pembelajaran inkuiri terbimbing terhadap prestasi belajar fisika pada siswa kelas VIII SMPN 1 Narmada).

\section{HASIL DAN PEMBAHASAN}

Instrument yang digunakan pada tahapan pretest dan psotest diuji terlebih dahulu untuk menentukan validitas, reliabilitas, daya beda, dan indeks kesukaran instrument tes yang telah disipakan. Ujicoba instrument tes diikuti 34 siswa di kelas VIII 2 SMPN 1 Narmada. Berdasarkan hasil ujicoba instrumen didapatkan 24 butir instrument tes yang dinyatakan valid dari 50 butir instrument tes yang diujikan. Secara ringkas hasil ujicoba instrument tes disajikan pada Tabel 5.

Tabel 5. Hasil Uji Coba Instrumen Penelitian

\begin{tabular}{|c|c|c|}
\hline & Uji Instrumen & Kriteria \\
\hline \multicolumn{3}{|r|}{$r_{x y}>r_{\text {tabel }}=$ Valid } \\
\hline Jumlah siswa & 34 siswa & $r_{x y}<r_{\text {tabel }}=$ InValid \\
\hline Jumlah Item Soal & 50 butir & \\
\hline Item Soal Valid & 24 butir & \\
\hline Item Soal Tidak Valid & 26 butir & \\
\hline \multicolumn{3}{|c|}{ Reliabilitas } \\
\hline Jumlah siswa & 34 siswa & \\
\hline Jumlah Item Soal & 50 butir & \\
\hline \multicolumn{3}{|c|}{ Daya Beda } \\
\hline Jumlah siswa & 34 siswa & $\mathrm{D}: 0,20-0,40=$ cukup \\
\hline Jumlah Item Soal & 50 butir & D:0,40-0,70 =baik \\
\hline Jelek & 21 butir & D:0,70-1,00 =baik sekali \\
\hline Cukup & 22 butir & \\
\hline Baik & 7 butir & \\
\hline Baik sekali & - & \\
\hline & Indeks Kesukaran & \multirow{6}{*}{$\begin{array}{l}P: 0,00-0,30=\text { mudah } \\
P: 0,30-0,70=\text { sedang } \\
P: 0,70-1,00=\text { sukar }\end{array}$} \\
\hline Jumlah siswa & 34 siswa & \\
\hline Jumlah Item Soal & 50 butir & \\
\hline Mudah & 13 butir & \\
\hline Sedang & 23 butir & \\
\hline Sukar & 14 butir & \\
\hline
\end{tabular}

Instrument tes yang dinyatakan valid, selanjutnya digunakan untuk mengambil data pretes dan pos-tes. Berdasarkan hasil pre-tes diperoleh nilai rata-rata pada kelompok eksperimen sebesar 36,17 dan 39,5 pada kelompok kontrol. Kegiatan penelitian dilanjutkan dengan kelas VIII.4 sebagai kelompok eksperimen yang diterapkan model pembelajaran Inkuiri terbimbing sedangkan kelas VIII.6 sebagai kelompok kontrol dibelajarkan menggunakan model konvensional. Kedua kelompok sampel penelitian dibelajarkan pokok bahasan yang sama yaitu materi pembiasan cahaya. Ringkasan hasil pre-tes kelompok eksperimen dan kelompok kontrol disajikan pada Tabel 6.

Tabel 6. Hasil Pre-tes siswa

\begin{tabular}{cccc}
\hline Kelas & Nilai tertinggi & Nilai terendah & Nilai rata-rata \\
\hline Eksperimen & 54 & 21 & 36,17 \\
Kontrol & 62 & 21 & 39,5 \\
\hline
\end{tabular}


Siswa kelompok eksperimen menunjukkan aktifitas dan ketertarikan yang lebih baik dibandingkan siswa pada kelompok kontrol. Keaktifan siswa dalam belajar menjadikan pembelajaran lebih menyenangkan karena dalam pelaksanaannya siswa tidak hanya mencatat apa yang disampaikan oleh guru tetapi terlibat langsung dalam menemukan jawaban dari permasalahan yang diberikan oleh guru sehingga menjadikan siswa bersikap obyektif, kreatif dan inovatif. Sejalan dengan hasil penelitian tersebut, Nisa et al (2018) menjelaskan bahwa model pembelajaran inkuiri berbasis pada pendekatan konstruktivis yang menekankan pada aktifitas siwa yang lebih banyak selama proses pembelajaran. Tidak mengherankan, hasil penelitian ini menunjukkan bahwa siswa menjadi lebih mandiri, dan saling membantu. Pemahaman siswa terhadap pelajaran dapat diserap dengan lebih cepat sehingga dapat berpengaruh terhadap kognitif siswa. Sedangkan di kelas kontrol, siswa lebih cenderung menerima apa yang disampaikan oleh guru dan mencatat langsung apa yang sudah dijelaskan. Sejalan dengan hasil penelitian tersebut, Khoiri et al (2020) menyebutkan bahwa dalam pembelajaran inkuri, siswa dituntut untuk berpikir seperti saintis yang mengedepankan aktifitas tubuh, pikiran, dan social dalam memecahkan masalah berdasarkan fakta empiris yang dimiliki melalui kegiatan sistematis melalui langkah-langkah saintifik.

Setelah proses pembelajaran dilakukan, dilakukan evaluasi (pos-tes) pada kedua kelas tersebut untuk melihat nilai akhir setelah mendapatkan perlakuan. Dari analisis post-tes yang telah dilakukan, diketahui bahwa hasil belajar siswa kelas eksperimen lebih baik daripada kelas kontrol. Nilai tertinggi kelas eksperimen adalah 87 sedangkan nilai tertinggi kelas kontrol 83. Nilai rata-rata kelas eksperimen adalah 65,41 sedangkan nilai rata-rata kelas kontrol adalah 50. Ringkasan hasil pre-tes kelompok eksperimen dan kelompok kontrol disajikan pada Tabel 7.

Tabel 7. Hasil Pos-tes siswa

\begin{tabular}{cccc}
\hline Kelas & Nilai tertinggi & Nilai terendah & Nilai rata-rata \\
\hline Eksperimen & 87 & 42 & 62,76 \\
Kontrol & 83 & 25 & 50 \\
\hline
\end{tabular}

Data hasil penelitian (post-test) terkait prestasi siswa juga dianalisis secara statistik menggunakan uji-t. Uji normalitas dan homogenitas data terlebih dahulu dilakukan sebagai prasyarat pengguaan uji-t untuk mengetahui pengaruh penggunaan model pembelajaran inkuiri terbimbing terhadap prestasi belajar siswa pada materi pembiasan cahaya. Tabel 8 dan Tabel 9 menunjukkan hasil uji normalitas dan homogenitas data penelitian secara ringkas.

Tabel 8. Hasil uji normalitas nilai pos-tes fisika siswa dari kedua kelompok.

\begin{tabular}{ccccccc}
\hline Kelompok & $\mathbf{X}^{2}{ }_{\text {hitung }}$ & $\mathbf{X}^{2}$ tabel & $\mathbf{d k}$ & Indeks Signifikan & Kesimpulan & Keterangan \\
\hline Eksperimen & 2,18 & 11,070 & 5 & $5 \%$ & Normal & Normal, jika \\
Kontrol & 3,75 & 11,070 & 5 & $5 \%$ & Normal & $\mathrm{X}^{2}{ }_{\text {hit }}<\mathrm{X}^{2}{ }_{\text {tab }}$ \\
\hline
\end{tabular}

Tabel 9. Ringkasan Uji Homogenitas varians nilai pos-tes siswa dari kedua kelompok

\begin{tabular}{ccccl}
\hline $\begin{array}{c}\text { Varians } \\
\text { Terbesar }\end{array}$ & $\begin{array}{c}\text { Varians } \\
\text { Terkecil }\end{array}$ & F-hitung & F-tabel & \multicolumn{1}{c}{ Keterangan } \\
\hline 225,67 & 145,65 & 1,54 & 1,82 & $\begin{array}{l}\text { Homogen jika F-hitung }<\text { F-tabel } \\
\text { pada taraf signifikan } 5 \%\end{array}$ \\
\hline
\end{tabular}

Berdasarkan kriteria pengujian, data penelitian dinyatakan berdistribusi normal $\left(\mathrm{X}^{2}\right.$ hit $<$ $\mathrm{X}^{2}$ tabel). Data penelitian selanjutnya diuji homogenitas dengan ketentuan, data dinyatakan homogen jika $F_{\text {hitung }}<F_{\text {tabel }}$. Hasil uji homogenitas data menunjukkan bahwa $F_{\text {hitung }}=1,54$ dan $F_{\text {tabel }}=1,82$ pada taraf signifikan $5 \%(0.05)$, sehingga dapat dinyatakan bahwa data post-tetst kedua sampel bervarian homogen. Berdasarkan uji prasyarat, analisis data dilanjutkan menggunakan uji-t untuk mengetahui pengaruh penggunaan model pembelajaran 
inkuiri terbimbing terhadap prestasi belajar siswa. Tabel 10 menunjukkan secara singkat hasil uji-t hipotesis penelitian.

Tabel 10. Ringkasan Hasil Uji Hipotesis

\begin{tabular}{ccccc}
\hline Variabel & Db & $\mathbf{t}$-hitung & $\mathbf{t}$-tabel & Keterangan \\
\hline Prestasi Belajar & 66 & 6,07 & 2,000 & Ha diterima jika t-hitung $>$ t-tabel
\end{tabular}

Hasil uji hipotesis menunjukkan bahwa $\mathrm{t}_{\text {-hitung }}=6,07$ dan $\mathrm{t}_{\text {-tabel }}=2,00$ (t-hitung $>\mathrm{t}$-tabel), sehingga, dapat disimpulkan bahwa hipotesis Ho ditolak yang artinya penggunaan model pembelajaran inkuiri pada materi pembiasan cahaya berpengaruh secara signifikan terhadap prestasi belajar siswa SMPN 1 Narmada. Hasil penelitian lain menunjukkan hasil serupa yang menemukan bahwa model pembelajaran inkuiri berpengaruh positif terhadap ketermapilan berpikir kritis siswa (Nisa et al., 2018). Lebih lanjut, hasil penelitian lain menunjukkan bahwa penggunaan model pembelajaran inkuiri terbimbing dengan bantuan lembar kerja siswa memberikan pengaruh positif terhadap kompetensi biologi siswa (Nurlaila \& Lufri, 2021).

\section{KESIMPULAN}

Hasil penelitian ini telah mencapai tujuan yang telah disrumuskan sebelumnya. Berdasarkan hasil penelitian dan analisis data maka dapat disimpulkan bahwa model pembelajaran inkuiri terbimbing berpangaruh terhadap prestasi belajar fisika siswa kelas VIII pada SMPN 1 Narmada pada pokok bahasan pembiasan cahaya.

\section{REKOMENDASI}

Peneltian ini hanya terbatas pada identifikasi pengaruh penggunaan model pembelajaran inkuiri terbimbing terhadap prestasi belajar siswa pada materi pembiasan cahaya, sehingga penelitian selanjutnya sangat penting untuk menguji pengaruh model pembelajaran inkuiri terbimbing pada materi ajar lain. Disamping itu, integrasi media pembelajaran baik media online maupun media nyata perlu diintegrasikan pada penelitian selanjutnya untuk lebih menarik minat belajar siswa sehingga pembelajaran lebih efektif dan aktif.

\section{UCAPAN TERIMAKASIH}

Ucapan terimakasih disampaikan kepada pihak sekolah yang telah memberikan izin penelitian dan membantu proses berjalannya pengambilan data selama penelitian. Selain itu, ucapan terimakasih juga disampaikan kepada sampel penelitian yang telah bersedia meluangkan waktu dan mengikuti proses penelitian secara sungguh-sungguh.

\section{DAFTAR PUSTAKA}

Anderson, L. W., \& Krathwohl, D. R. (Eds.). (2001). A taxonomy for learning, teaching, and assessing: A revision of Bloom's taxonomy of educational objectives (Complete ed). Longman.

Arends, R. (2012). Learning to teach (9th ed). McGraw-Hill.

Arikunto, S. (2013). Dasar-dasar Evaluasi Pendidikan (edisi 2). Bumi Aksara. https://ecampusfip.umj.ac.id/pustaka_umj/main/item/14939

Asy'ari, M., Ikhsan, M., \& Mühali, M. (2019). The Effectiveness of Inquiry Learning Model in Improving Prospective Teachers' Metacognition Knowledge and Metacognition Awareness. International Journal of Instruction, 12(2), 455-470. https://doi.org/10.29333/iji.2019.12229a

Fraenkel, J. R., Wallen, N. E., \& Hyun, H. H. (2012). How to design and evaluate research in education (8th ed). McGraw-Hill Humanities/Social Sciences/Languages.

Gulo, W. (2008). Strategi belajar mengajar. Grasindo.

Hosnan, M. (2014). Pendekatan saintifik dan kontekstual dalam pembelajaran abad 21. Ghalia Indonesia.

Khoiri, N., Huda, C., Rusilowati, A., Wiyanto, W., Sulhadi, S., \& Wicaksono, A. G. C. (2020). The Impact of Guided Inquiry Learning with Digital Swing Model on Students' Generic 
Science Skill. Jurnal Pendidikan IPA Indonesia, 9(4), 554-560. https://doi.org/10.15294/jpii.v9i4.26644

Nisa, E. K., Koestiari, T., Habibbulloh, M., \& Jatmiko, B. (2018). Effectiveness of guided inquiry learning model to improve students' critical thinking skills at senior high school. Journal of Physics: Conference Series, 997, 012049. https://doi.org/10.1088/1742$6596 / 997 / 1 / 012049$

Nurlaila, N., \& Lufri, L. (2021). The effect of guided inquiry learning models using the help of student activity sheet on the knowledge competency of students in class xi of SMAN 1 Sungayang. Journal of Physics: Conference Series, 1940(1), 012120. https://doi.org/10.1088/1742-6596/1940/1/012120

Prayogi, S., Hidayat, S., \& Wulandara, A. (2013). Penerapan Model Pembelajaran Kooperatif dengan Strategi Pembelajaran Poe (Predict Observe Explain) untuk Meningkatkan Hasil Belajar dan Kemampuan Berpikir Kritis Siswa di MAN 1 Mataram Tahun Pelajaran 2012/2013. Lensa: Jurnal Kependidikan Fisika, 1(1), 28. https://doi.org/10.33394/j-lkf.v1i1.70

Riduwan. (2008). Skala pengukuran variabel-variabel penelitian. Alfabeta. https://opac.perpusnas.go.id/DetailOpac.aspx?id=350661

Subana, M., \& Sudrajat. (2009). Dasar-dasar penelitian ilmiah. Pustaka Setia.

Sukaisih, R., \& Muhali, M. (2014). Meningkatkan Kesadaran Metakognitif dan Hasil Belajar Siswa Melalui Penerapan Pembelajaran Problem Solving. Prisma Sains: Jurnal Pengkajian IImu Dan Pembelajaran Matematika Dan IPA IKIP Mataram, 2(1), 71. https://doi.org/10.33394/j-ps.v2i1.803

Sukaisih, R., Muhali, M., \& Asy'ari, M. (2020). Meningkatkan keterampilan metakognisi dan berpikir kritis siswa melalui pembelajaran model pemecahan masalah dengan strategi konflik-kognitif. Empiricism Journal, 1(1), 37-50. https://doi.org/10.36312/ej.v1i1.329

Sukarma, I. K., \& Sani, F. R. (2020). Penerapan model pembelajaran problem based instruction (pbi) untuk meningkatkan aktivitas dan prestasi belajar siswa. Empiricism Journal, 1(2), 66-74. https://doi.org/10.36312/ej.v1i2.335

Sumantri, B. A. (2019). Pengembangan Kurikulum di Indonesia Menghadapi Tuntutan Kompetensi Abad 21. EL-HIKMAH: Jurnal Kajian Dan Penelitian Pendidikan Islam, 13(2), 146-167. https://doi.org/10.20414/elhikmah.v13i2.661

Suwandi, S., Tawil, M., \& Amin, B. D. (2013). Upaya Meningkatkan Hasil Belajar Fisika dengan Pendekatan Pembelajaran Problem Solving pada Siswa Kelas XI IPA1 SMA Negeri 1 Parangloe. Jurnal Pendidikan Fisika, 1(2), 129-138. https://doi.org/10.26618/jpf.v1i2.196

Trianto. (2012). Model Pembelajaran Terpadu: Konsep, strategi, dan implementasinya dalam Kurikulum Tingkat Satuan Pendidikan (KTSP). Bumi Aksara. //library.fis.uny.ac.id\%2Fopac\%2Findex.php\%3Fp\%3Dshow_detail\%26id\%3D1227\% 26keywords\%3D

Wenning, C. J. (2011). The Levels of Inquiry Model of Science Teaching (Shaded sections added January 2012; refer to Wenning (2010) for explications of real-world applications component of the Inquiry Spectrum.). Journal of Physics Teacher Education Online, 6(2), 8. 